\title{
Dynamics of drinking water biofilm in flow/non-flow conditions
}

\author{
C.M. Manuel, O.C. Nunes, L.F. Melo* \\ LEPAE, Department of Chemical Engineering, Faculty of Engineering, University of Porto, Rua Dr. Roberto Frias, $4200-465$ Porto, Portugal
}

\section{A R T I C L E I N F O}

Article history:

Received 25 October 2005

Received in revised form

25 October 2006

Accepted 6 November 2006

Available online 20 December 2006

Keywords:

Drinking water

Biofilm

Specific growth rates

Materials

\begin{abstract}
A B S T R A C T
Drinking water biofilm formation on polyvinyl chloride (PVC), cross-linked polyethylene (PEX), high density polyethylene (HDPE) and polypropylene (PP) was followed in three different reactors operating under stagnant or continuous flow regimes. After one week, a quasi-steady state was achieved where biofilm total cell numbers per unit surface area were not affected by fluctuations in the concentration of suspended cells. Metabolically active cells in biofilms were around $17-35 \%$ of the total cells and $6-18 \%$ were able to form colony units in $\mathrm{R}_{2} \mathrm{~A}$ medium. Microbiological analysis showed that the adhesion material and reactor design did not affect significantly the biofilm growth. However, operating under continuous flow (0.8-1.9 Pa) or stagnant water had a significant effect on biofilm formation: in stagnant waters, biofilm grew to a less extent. By applying mass balances and an asymptotic biofilm formation model to data from biofilms grown on PVC and HDPE surfaces under turbulent flow, specific growth rates of bacteria in the biofilm were found to be similar for both materials (around 0.15 day $^{-1}$ ) and much lower than the specific growth rates of suspended bacteria (around 1.8 day $^{-1}$ ).
\end{abstract}

(c) 2006 Elsevier Ltd. All rights reserved.

\section{Introduction}

In drinking water distribution systems, the density of suspended bacteria increases between the treatment plant and the consumer's tap as a function of the disinfectant decay, hydraulic residence time, substrate uptake and the presence of corrosion deposits. In a drinking water distribution system where the volume/surface area ratio is $5 \mathrm{~cm}$, Flemming et al. (2002) estimated that $95 \%$ of the overall biomass is attached to pipe walls, while only $5 \%$ is in the water phase. Therefore, the development of bacteria in biofilms is highly relevant for water quality since it may directly affect cell density in the bulk water phase through detachment phenomena (van der Wende et al., 1989), which depend on a variety of factors such as hydrodynamic patterns and surface materials.

Many drinking water distribution networks are designed for target liquid velocities of $0.2-0.5 \mathrm{~m} / \mathrm{s}$. In most fixed biomass systems, stable and higher flow rates have the advantage of limiting biofilm growth (Peyton and Characklis, 1993; Melo and Vieira, 1999; Cloete et al., 2003), since they produce thinner and more cohesive layers less prone to release bacteria into the bulk water. However, these conditions are not always feasible to maintain in drinking water networks. The hydraulic conditions in drinking water systems range from laminar to turbulent flow, but stagnant (non-flow) waters also occur in places where the water consumption is low, as well as in reservoirs in buildings. Reports on drinking water biofilms in stagnant conditions are rare. Momba and Kaleni (2002) studied the regrowth of microorganisms on polyethylene (PE) and galvanized steel surfaces of household containers used for storage of drinking water and observed higher values of colony formation units (CFU) and dissolved organic carbon (DOC) for PE after storing water for $48 \mathrm{~h}$.

*Corresponding author.

E-mail address: Imelo@fe.up.pt (L.F. Melo).

0043-1354/\$ - see front matter (c) 2006 Elsevier Ltd. All rights reserved.

doi:10.1016/j.watres.2006.11.007 


$\begin{array}{ll}\text { Nomenclature } \\ \text { A } & \text { internal surface area, } \mathrm{cm}^{2} \\ Q & \text { flow rate of recirculation, } \mathrm{mL} / \text { day } \\ Q_{\text {ext }} & \text { inlet flow rate, } \mathrm{mL} / \text { day } \\ t & \text { time,day, } \mathrm{h} \\ \mathrm{T} & \text { temperature, }{ }^{\circ} \mathrm{C} \\ \mathrm{V} & \text { volume of the system, } \mathrm{mL} \\ \mathrm{X} & \text { bulk suspended cell density, cell/mL } \\ X_{\mathrm{b}} & \text { biofilm cell number per unit surface area, cell } / \mathrm{cm}^{2} \\ \left(\mathrm{X}_{\mathrm{b}}\right)_{\mathrm{max}} & \text { steady-state biofilm cell number per unit surface } \\ & \text { area, cell/cm }{ }^{2} \\ X_{\mathrm{in}} & \text { inlet suspended cell density, cell/mL } \mathrm{mL} \\ \mathrm{X}^{*} & \text { steady state bulk suspended cell density, cell/mL }\end{array}$

Greek symbols

$\beta^{-1} \quad$ average residence time of cells within the biofilm, day

$\Phi_{\text {att }} \quad$ rate of cell attachment to the surface, cells $/ \mathrm{h}$
$\Phi_{\text {det }} \quad$ biofilm detachment or removal rate, cells $/ \mathrm{h}$

$\Phi_{\mathrm{p}} \quad$ biomass production rate in the biofilm, cells $/ \mathrm{h}$

$\mu_{\text {biofilm }}$ specific cell growth rate inside the biofilm, day ${ }^{-1}$

$\mu_{\text {bulk }} \quad$ specific cell growth rate in suspension, day ${ }^{-1}$

$\mu_{\text {overall overall specific cell growth rate, } \text { day }^{-1}}$

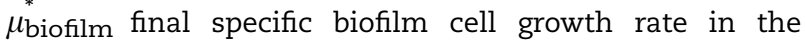
biofilm, day ${ }^{-1}$

$\mu_{\text {bulk }}^{*} \quad$ steady state value of specific cell growth rate in suspension, day ${ }^{-1}$

$\mu^{*}$ overall steady state value of overall specific cell growth rate, day $^{-1}$

List of abbreviations

HDPE high density polyethylene

PEX cross-linked polyethylene

PMMA polymethyl methacrylate

PP polypropylene

PVC polyvinyl chloride
LeChevallier et al. (1987) obtained high bacterial counts in drinking water after opening a tap that was turned off overnight.

There is still some controversy about the effect of surface materials on biofilm development. In the past, the majority of pipelines in drinking water networks were made of iron-based or cement-based materials. More recently, polymeric materials have been preferred, mainly polyvinyl chloride (PVC) and PE, because they are easier to handle and implement. Some researchers (Kerr et al., 1999; Niquette et al., 2000; Momba and Kaleni, 2002) demonstrated that drinking water biofilms grew less on polymeric materials (PE, PVC, Teflon) than on iron matrices (grey iron, cast iron, galvanized steel, cemented steel, asbestos-cement and cemented cast iron). This fact was attributed to iron corrosion products that favour biofilm protection from the effect of flow rate and of disinfectants. The same study showed that there was no significant difference in the viable counts on PE and PVC. Different results were obtained by Cloete et al. (2003), where biofilm formation was higher on the PVC surfaces than on galvanized steel piping. van der Kooij and Veenendaal (2001) and Clark et al. (1994) observed that PE supports biofilm formation in a higher degree than PVC, while Wingender and Flemming (2004), Pedersen (1990) and Zacheus et al. (2000) concluded that there was no significant difference in the colonization of the investigated materials (stainless steel, PVC and PE), in some cases after decades of operation. Lethola et al. $(2004,2005)$ found that biofilms grew faster in PE than in copper pipes, but such differences could not be detected in older piping systems; these authors also studied the release of nutrients from the surface materials to the bulk water and the deleterious effects that this may cause on the water quality and on the efficacy of chlorine disinfection.

Another point of interest is the metabolic state of the cells in suspension and in biofilms, since it can be a measure of their growing potential and, therefore, of the risk of water contamination. Wingender and Flemming (2004) observed that the cultivable cells were at most $3.5 \%$ of the total cells in biofilms aging from 2 to 99 years. Boe-Hansen et al. (2002a) reported that the highest percentages (up to 24\%) were observed in the youngest biofilms in an assay of 522 days. Schwartz et al. (1998) studied the development of biofilms on high density polyethylene (HDPE), PVC, steel and copper in contact with drinking water collected at the water works and in house branch connections: the biofilm densities of cultivable bacteria on the different materials were about one order of magnitude less than the total cell number; $35-38 \%$ of the bacteria were metabolically active, except for copper (less than 10\%). Schaule et al. (1993) also found that the percentage of metabolically active bacteria in biofilms sampled within the distribution system was about $30-35 \%$.

There is a lack of information on the kinetics of bacterial growth in drinking water biofilms as compared to suspended bacteria. Authors studying wastewaters and industrial waters are divided between those who defend that the activity of sessile and planktonic bacteria is similar (Bakke et al., 1984; Characklis and Marshall, 1990) and those who reached opposite conclusions (Plas et al., 1994; Le Magrex et al., 1994). Quantitative data on bacterial growth kinetics in drinking water systems is scarce (Pedersen, 1990; Block et al., 1993; Boe-Hansen et al., 2002b), although such data would seem important for the proper design of distribution networks and reservoirs. The values of biofilm specific growth rates reported by these authors range between 0.03 day $^{-1}$ and 0.06 day $^{-1}$.

In this paper, two continuous flow reactors and one nonstirred batch reactor were used in drinking water studies with a three-fold goal: (a) to investigate the effect of the flow/nonflow regimes on the growth of both attached and suspended bacteria; (b) to determine specific growth rates of biofilm bacteria and compare these values to those obtained with 
planktonic cells; (c) to test the effect of the surface material on the development of biofilm and suspended cells.

\section{Methods}

\subsection{Biofilm monitoring reactors}

The tested monitoring systems were a Batch reactor, a Propella ${ }^{\circledR}$ reactor and a Flow Cell reactor, their main characteristics being described in Table 1. The last two reactors are schematically represented in Fig. 1.

Biofilms were formed on adhesion coupons made of several materials placed within the reactors in contact with drinking water under different operating conditions, including stagnant and continuous flow regimes. The tested material coupons were PVC, cross-linked polyethylene (PEX), HDPE and polypropylene (PP).

The Batch reactor was a non-stirred cylindrical glass vessel (12 cm internal diameter) operating as a closed system, filled up with $1.5 \mathrm{~L}$ of drinking water at the beginning of the experiment. Twenty coupons (plates of $1.0 \mathrm{~cm} \times 2.0 \mathrm{~cm} \times$ $0.15 \mathrm{~cm}$ ) were immersed in the bulk water in a vertical position, at 2 to $7 \mathrm{~cm}$ from the bottom, suspended by plastic wires in the central part of the vessel. The contact area between the plastic wire and the coupon was around $0.03 \mathrm{~cm}^{2}$, which corresponds to $0.6 \%$ of the total area. Propella ${ }^{\circledR}$ was a perfectly mixed continuous reactor with two concentric cylinders (internal cylinder with $D_{\text {in }}=44 \mathrm{~mm}$, $D_{\text {ext }}=72.5 \mathrm{~mm}$ and $h=460 \mathrm{~mm}$; external cylinder with $D_{\text {in }}=93.4 \mathrm{~mm}$ and $h=500 \mathrm{~mm}$ ), in which a propeller pushed the liquid down through the internal tube and up through the annular section between the two tubes. It allowed an

\section{Table 1 - Characteristics of the biofilm monitoring reactors}

\begin{tabular}{lccc}
\hline Parameters & Propella ${ }^{\circledR}$ & Flow Cell & Batch reactor \\
\hline Material & PVC and stainless steel 316 L & Perspex (PMMA) & Glass \\
Internal volume (L) & 2.23 & 0.34 & 1.50 \\
Vol/area (cm) & 0.67 & 1.25 & 2.41 \\
Biofilm sampling points & 20 & 10 & 20 \\
Biofilm sampling area $\left(\mathrm{cm}^{2}\right)$ & 2.0 & PVC, HDPE, PEX and PP & 4.9 \\
Coupons materials & & & 2.0 \\
\end{tabular}

PMMA_Polymethyl methacrylate; HDPE—High density polyethylene; PP_Polypropylene; PVC—Polyvinyl chloride; PEX—Cross-linked polyethylene.
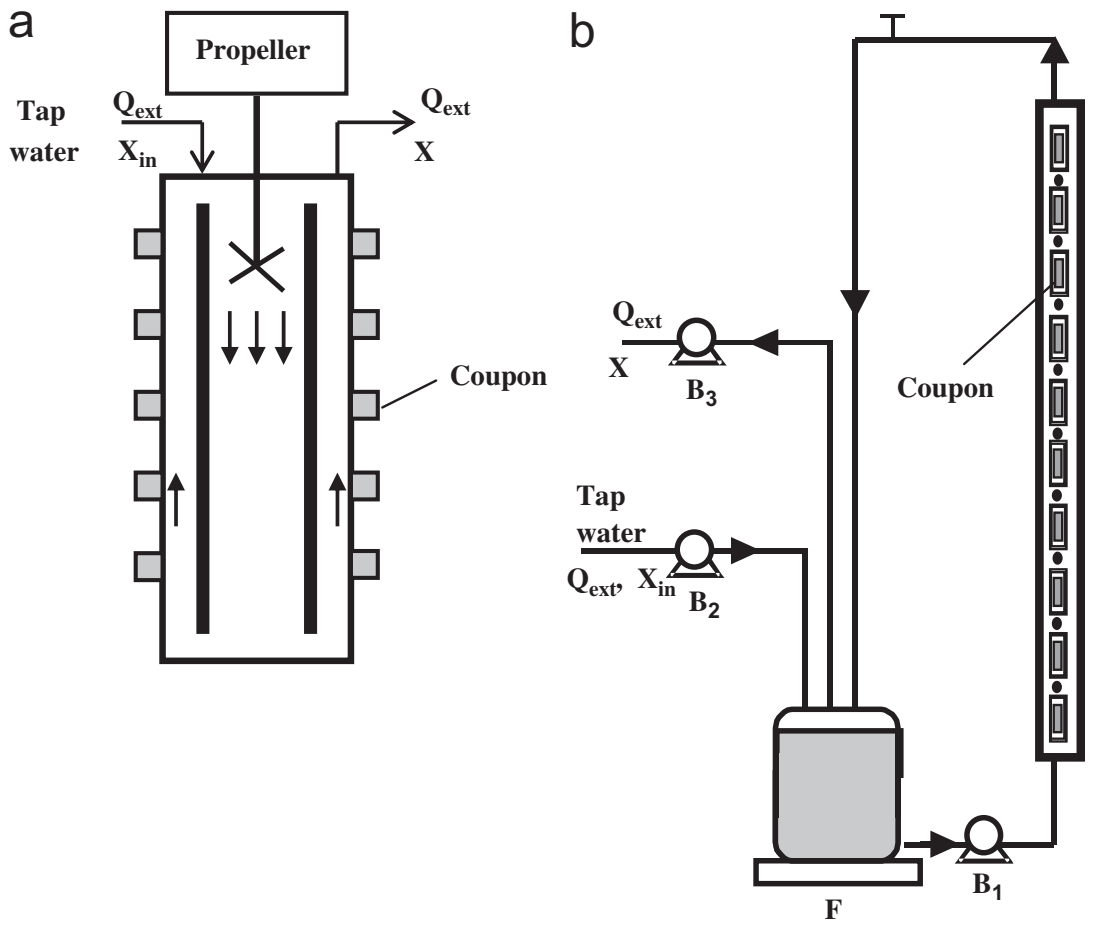

Fig. 1 - (a) Propella ${ }^{\circledR}$ reactor; (b) Flow Cell reactor. 
Table 2 - Measured physical, chemical and microbiological parameters of Porto drinking water

\begin{tabular}{|c|c|}
\hline Parameters & Drinking water \\
\hline $\mathrm{T}\left({ }^{\circ} \mathrm{C}\right)$ & $15.9 \pm 0.7$ \\
\hline $\mathrm{pH}$ & $7.3 \pm 0.3$ \\
\hline $\mathrm{O}_{2}\left(\mathrm{mg} \mathrm{O}_{2} / \mathrm{L}\right)$ & $8.4 \pm 0.6$ \\
\hline IC $(\mathrm{mg} \mathrm{C} / \mathrm{L})$ & $16.25 \pm 0.06$ \\
\hline TOC-Total Organic Carbon (mg C/L) & $2.32 \pm 0.35$ \\
\hline DOC-Dissolved Organic Carbon (mg C/L) & $2.12 \pm 0.47$ \\
\hline $\mathrm{K}$-water conductivity $(\mu \mathrm{S} / \mathrm{cm})$ & $168.7 \pm 15.8$ \\
\hline Chlorine $\left(\mathrm{mg} \mathrm{Cl}_{2} / \mathrm{L}\right)$ & $0.15 \pm 0.03$ \\
\hline $\mathrm{NH}_{3}^{-}$-Nitrogen $(\mathrm{mg} \mathrm{N} / \mathrm{L})$ & $<0.01$ \\
\hline $\mathrm{NO}_{3}^{-}$-Nitrogen $(\mathrm{mg} \mathrm{N} / \mathrm{L})$ & $1.66 \pm 0.11$ \\
\hline $\mathrm{NO}_{2}^{-}$-Nitrogen $(\mathrm{mg} \mathrm{N} / \mathrm{L})$ & $<0.01$ \\
\hline Total phosphorous (mgP/L) & $0.013 \pm 0.002$ \\
\hline Total cell density (cell/mL) & $4.4 \times 10^{5} \pm 1.2 \times 10^{5}$ \\
\hline Metabolically active cell density (cell/mL) & $1.8 \times 10^{5} \pm 1.6 \times 10^{4}$ \\
\hline $\mathrm{R}_{2} \mathrm{~A}$-cultivable cell density (cell/mL) & $2.0 \times 10^{3} \pm 2.1 \times 10^{2}$ \\
\hline
\end{tabular}

independent choice of the internal velocity and the hydraulic residence time. The flow rate inside the pipe was controlled by the rotation speed of the propeller and the residence time is proportional to the fresh inlet flow rate. Detailed features of this reactor can be found in Batté et al. (2003).

The Flow Cell had a semi-circular cross section with an internal diameter of $3.2 \mathrm{~cm}$ and contained the coupons on its flat surface. The system composed by the Flow Cell, vessel F and recirculating tubes approaches a perfectly mixed reactor due to the high recirculating flow rates. Pumps $B_{1}$ and $B_{2}$ controlled the internal velocity and the residence time, respectively. This system also allowed to uncouple the system residence time and the fluid velocity. The basic concept and characteristics of the Flow Cell were reported by Pereira et al. (2002).

The Propella ${ }^{\circledR}$ and Flow Cell reactors were connected to the drinking water distribution system in the town of Porto, whose characteristics are presented in Table 2. The same water was used to fill up the Batch reactor.

Before each experiment, the reactors were cleaned with a chlorine solution and then with a mild detergent solution (non-ionic, neutral pH, phosphate-free-25\% Aquet, SCIENCEWARE). Finally, the reactors were rinsed abundantly with tap water and then with sterile dionized water.

\subsection{Operating conditions}

Several assays were carried out in order to evaluate biofilm dynamics and bacterial growth kinetics, as well as to compare surface materials.

In the first set of assays (RUN 1), Propella ${ }^{\circledR}$, Flow Cell and Batch reactors were operated for 56 days using the same surface test materials (PVC, HDPE, PEX and PP). The continuous flow reactors were fed with Porto drinking water at appropriate inlet flow rates $\left(Q_{\text {ext }}\right)$ in order to obtain equal hydraulic residence times (HRT), internal velocities $\left(u_{\text {int }}\right)$ and wall shear stresses $\left(\tau_{\mathrm{w}}\right)$ in both systems (Table 3 ). Biofilm and bulk water samples were removed at predefined days and several physical, chemical and microbiological parameters were measured, such as total, metabolically active and $\mathrm{R}_{2} \mathrm{~A}$ cultivable cell numbers, TOC and DOC, $\mathrm{pH}$, conductivity and temperature. Additionally, the effect of the continuous flow (Propella ${ }^{\circledR}$ and Flow Cell reactors) versus stagnant water (Batch reactor) regimes on biofilm growth was assessed.

A second assay (RUN 2) was performed only in the Flow Cell, using PVC and HDPE, with a higher internal flow rate (and consequently, higher shear stress). The operating conditions are also presented in Table 3. In the first four days of this run, samples were collected every $12 \mathrm{~h}$. From day 5 up to day 28, samples were collected at a rate of one per week. From this experiment, the initial stages of biofilm growth on PVC and HDPE were observed, as well as the effect of shear stress under turbulent flow regime. Cell numbers obtained were used to determine biofilm growth rates and to compare the effect of the surface material on the biofilm adhesion.

Temperature was not controlled inside the reactors since the purpose was to observe the biofilm growth under the conditions prevailing in the actual drinking water system of Porto.

\subsection{Sampling}

Biofilm samples were collected by removing test coupons from the reactors. The coupons were then immersed in a flask containing $25 \mathrm{~mL}$ of sterile bacteria-free saline solution $(0.85 \%(\mathrm{w} / \mathrm{v}) \mathrm{NaCl})$. The flask with the coupon was gently sonicated for $10 \mathrm{~min}$ (sonication bath Transsonic 420 ELMA, $70 \mathrm{~W}, 35 \mathrm{kHz}$ ) to release the attached bacteria into the suspension. The percentage of cells not detached from the surface by sonication was less than $0.3 \%$. At the same time, $50 \mathrm{~mL}$ of the water inside the reactors and of the inlet drinking water flow were collected to a sterile flask.

\subsection{Count of bacteria total number}

The enumeration of the suspended bacteria from bulk water of the reactors, inlet tap water and biofilm was performed by the 4', 6-Diamidino-2-Phenylindole (DAPI, SIGMA) staining method as described by Brunk et al. (1979). Samples were gently homogenized in vortex for $2 \mathrm{~min}$ and a small volume (0.5-4 mL) was filtered through a $0.22 \mu \mathrm{m}$ black polycarbonate membrane (Nucleopore). When bacteria were aggregated, a surfactant X-100 [000.1\%(w/v) Triton] was added to disperse the cells in suspension. After 10 min of incubation with $200 \mu \mathrm{L}$ of $0.5 \mu \mathrm{g} / \mathrm{mL}$ DAPI solution in the dark, the polycarbonate membrane was washed and mounted with non-fluorescent immersion oil on glass microscope slides. The membranes were examined using an epifluorescence microscope (LEICA DMLB2) with $1000 \times$ magnification and filter cube with the following characteristics: excitation filter $340-380 \mathrm{~nm}$, dichromatic mirror $400 \mathrm{~nm}$ and suppression filter LP 425. A minimum of 300 cells or a sufficient number of microscopic fields were counted in order to obtain a coefficient of variation of less than $30 \%$. 
Table 3 - Operating conditions in the biofilm monitoring reactors

\begin{tabular}{|c|c|c|c|c|}
\hline & \multicolumn{3}{|c|}{ RUN 1} & \multirow{2}{*}{$\begin{array}{c}\text { RUN } 2 \\
\text { Flow Cell }\end{array}$} \\
\hline & Propella $^{\circledR}$ & Flow Cell & Batch reactor & \\
\hline$u_{\text {int }}(\mathrm{m} / \mathrm{s})$ & 0.20 & 0.21 & 0 & 0.34 \\
\hline$Q_{\text {ext }}(\mathrm{mL} /$ day) & 7.8 & 15.1 & 0 & 15.1 \\
\hline Re (Reynolds no.) & 3970 & 5000 & 0 & 8293 \\
\hline$\tau_{\mathrm{w}}(\mathrm{Pa})$ & 0.80 & 0.80 & 0 & 1.91 \\
\hline HRT (h) & 11.9 & 12.0 & 1340 & 12 \\
\hline
\end{tabular}

\subsection{Count of $R_{2} A$-cultivable bacteria number}

Counts of $\mathrm{R}_{2} \mathrm{~A}$-cultivable bacteria were estimated by the spread plating method using $100 \mu \mathrm{L}$ of samples or dilutions thereof from dispersed biofilm, bulk water and inlet drinking water, using $\mathrm{R}_{2} \mathrm{~A}$-agar medium (Reasoner and Geldreich, 1985). The cultures were incubated for 7 days at $22^{\circ} \mathrm{C}$.

\subsection{Count of metabolically active bacteria number}

The redox dye CTC (5-cyano-2,3-ditolyl tetrazolium chloride, Polysciences) was employed to quantify the metabolically active bacteria (Rodriguez et al., 1992; Schaule et al., 1993) in dispersed biofilm, bulk water and inlet drinking water samples. The samples were incubated with $4 \mathrm{mM} \mathrm{CTC}$ solution and $9 \% \mathrm{R}_{2} \mathrm{~B}$ medium for $4 \mathrm{~h}$ in the dark at $28^{\circ} \mathrm{C}$ and $200 \mathrm{rpm}$. Then the stained suspension was filtered through a $0.22 \mu \mathrm{m}$ black polycarbonate membrane and the metabolically active bacteria were examined at $1000 \times$ magnification using the epifluorescent microscope with a LEICA filter cube with the following characteristics: excitation filter $515-560 \mathrm{~nm}$, dichromatic mirror $580 \mathrm{~nm}$ and suppression filter LP 590. The enumeration of cells was done as described above (Section 2.4).

\subsection{Total and dissolved organic carbon}

The total organic carbon (TOC) and the DOC were determined for the bulk water and inlet drinking water following the procedures described in the European Standard CEN 1484. TOC values were obtained in triplicate by subtracting the values of the total carbon (TC) and the inorganic carbon (IC) measured in a non-dispersive infrared gas SHIMADZU Analyzer (TOC-5000A).

The DOC was obtained following the described procedure with the samples pre-filtered through a $0.45 \mu \mathrm{m}$ glass fiber membrane (ALBET).

\subsection{Mass balances and cell number kinetics}

The cell growth rates in biofilm and bulk water were determined by counting the cell total numbers obtained from bulk water, tap water and biofilm samples.

Consider the cell balance in the reactor represented in Fig. 2. The accumulation of cells in bulk is related to the net

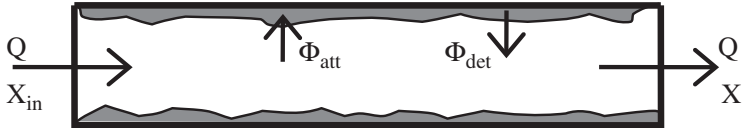

Fig. 2 - Bulk water cell balance in the reactor system. ( $\Phi_{\text {att }}-$ rate of cell attachment; $\Phi_{\text {det }}$-rate of cell detachment from the surface; $Q$ - water flow rate; $X_{i n}$-inlet water cell density; $\mathbf{X}$-outlet water cell density (= reactor bulk water cell density, assuming a perfectly mixed system).

transport through the inlet and outlet, the cell removal and attachment to the biofilm, as well as to the bulk phase net growth, and it can be expressed by the following equation:

$\mathrm{V} \frac{\mathrm{dX}}{\mathrm{dt}}=\mathrm{Q}\left(\mathrm{X}_{\mathrm{in}}-\mathrm{X}\right)+\mu_{\mathrm{bulk}} \mathrm{VX}-\Phi_{\mathrm{att}}+\Phi_{\text {det }}$,

where $V$ is the volume of the system $(\mathrm{mL}), Q$ is the inlet flow rate (mL/day), $X_{\text {in }}$ and $X$ are the suspended cell densities (cell/ $\mathrm{mL}$ ) in the inlet and outlet water, respectively, $X_{\mathrm{b}}$ is the biofilm cell number per unit surface area (cell $\left./ \mathrm{cm}^{2}\right), \Phi_{\text {det }}$ is the biofilm removal rate (cells/day), $\Phi_{\text {att }}$ is the rate of cell attachment to the surface (cells/day) and $\mu_{\text {bulk }}$ is the specific cell growth rate in suspension $\left(\mathrm{day}^{-1}\right)$. The cell balance related to the biofilm phase is expressed by

$\mathrm{A} \frac{\mathrm{dX}}{\mathrm{dt}}=\Phi_{\mathrm{p}}-\Phi_{\text {det }}$,

where $A$ is the internal surface area $\left(\mathrm{cm}^{2}\right)$ and $\Phi_{\mathrm{p}}$ is the biofilm production rate (cells/day) in the biofilm. Eq. (2) describes biofilm development over time as the result of the competition between a biomass production process (which includes attachment of new cells and cell growth within the biofilm) and a biomass removal process (whereby the rate of cells removed from the biofilm to the bulk water increases with the number of cells already attached)

$\Phi_{\mathrm{p}}=\mu_{\text {biofilm }} \mathrm{X}_{\mathrm{b}} \mathrm{A}+\Phi_{\mathrm{att}}$,

$\Phi_{\text {det }}=\beta \mathrm{X}_{\mathrm{b}} \mathrm{A}$,

where $\mu_{\text {biofilm }}$ is the specific cell growth rate inside the biofilm $\left(\right.$ day $^{-1}$ ) and $1 / \beta$ represents the average residence time of cells within the biofilm.

An overall biofilm model can then be established considering the following cell number balance in the biofilm over time (Characklis and Marshall, 1990; Melo and Bott, 1997; Melo and 
Table 4 - Physico-chemical parameters of bulk water

\begin{tabular}{|c|c|c|c|c|}
\hline & \multicolumn{3}{|c|}{ RUN 1} & \multirow{2}{*}{$\begin{array}{c}\text { RUN } 2 \\
\text { Flow Cell }\end{array}$} \\
\hline & Propella $^{\circledR}$ & Flow Cell & Batch & \\
\hline $\mathrm{T}\left({ }^{\circ} \mathrm{C}\right)$ & $18.5 \pm 2.1$ & $21.0 \pm 1.4$ & $20.2 \pm 1.0$ & $22.3 \pm 1.3$ \\
\hline $\mathrm{pH}$ & $7.4 \pm 0.1$ & $7.4 \pm 0.1$ & $7.4 \pm 0.1$ & $7.5 \pm 0.2$ \\
\hline $\mathrm{O}_{2}\left(\mathrm{mg} \mathrm{O}_{2} / \mathrm{L}\right)$ & $7.6 \pm 0.9$ & $6.2 \pm 1.1$ & $7.2 \pm 1.1$ & ND \\
\hline IC (mg C/L) & $16.31 \pm 0.09$ & $16.22 \pm 0.14$ & $15.53 \pm 0.13$ & $16.72 \pm 0.56$ \\
\hline TOC (mg C/L) & $2.07 \pm 1.28$ & $3.88 \pm 1.12$ & $3.25 \pm 0.67$ & $3.56 \pm 1.77$ \\
\hline $\mathrm{DOC}(\mathrm{mgC} / \mathrm{L})$ & $2.10 \pm 1.05$ & $3.77 \pm 0.94$ & $3.28 \pm 0.68$ & $3.39 \pm 0.45$ \\
\hline $\mathrm{K}(\mathrm{mS} / \mathrm{cm})$ & $260 \pm 43$ & $247 \pm 12$ & $257 \pm 10$ & $236 \pm 20$ \\
\hline
\end{tabular}

Vieira, 1999):

$\mathrm{A} \frac{\mathrm{dX}}{\mathrm{dt}}=\Phi_{\mathrm{p}}-\beta \mathrm{X}_{\mathrm{b}} A$

Considering the assumption that $\Phi_{\mathrm{p}}=$ constant, which was demonstrated by Melo and Vieira (1999) and Pereira et al. (2002), the integration of Eq. (5) leads to

$\mathrm{X}_{\mathrm{b}}=\left(\mathrm{X}_{\mathrm{b}}\right)_{\max }\left(1-\mathrm{e}^{-\beta \mathrm{t}}\right)$

and

$$
\left(\mathrm{X}_{\mathrm{b}}\right)_{\max }=\frac{\Phi_{\mathrm{p}}}{\mathrm{A} \beta},
$$

where $\left(X_{b}\right)_{\max }$ is the steady-state biofilm cell number per unit surface area. Similar asymptotic models have been shown to describe biofilm dynamics over time by several authors (Characklis and Marshall, 1990; Belkhadir et al., 1988).

Although the number of cells in suspension might be important for the start up of biofilm formation on surfaces, cell attachment to the surface does not seem to affect biofilm development in a significant way after those initial moments, as confirmed experimentally (Bott and Miller, 1983, and Melo and Vieira, 1999). Therefore, Eq. (3) can be simplified into

$\Phi_{\mathrm{p}}=\mu_{\mathrm{biofilm}} \mathrm{X}_{\mathrm{b}} \mathrm{A}$.

Therefore, at steady-state, the (final) specific biofilm cell growth rate in the biofilm, $\mu_{\text {biofilm }}^{*}$, is related to the final cell number per unit surface area, $\left(\mathrm{X}_{\mathrm{b}}\right)_{\max }$, and the biofilm production rate, $\Phi_{\mathrm{p}}$, by the following equation:

$\mu_{\text {biofilm }}^{*}=\frac{\Phi_{\mathrm{p}}}{\left(\mathrm{X}_{\mathrm{b}}\right)_{\max } A}$,

which means that cell growth in the biofilm in steady state is equal to the cell detachment from biofilm.

In order to determine $\mu_{\mathrm{bulk}}$, Eqs. (1) and (2) were added and at steady state (the time derivatives are zero):

$0=\mathrm{Q}\left(\mathrm{X}_{\mathrm{in}}-\mathrm{X}^{*}\right)+\mu_{\mathrm{bulk}}^{*} \mathrm{X}^{*} \mathrm{~V}+\mu_{\mathrm{biofilm}}^{*}\left(\mathrm{X}_{\mathrm{b}}\right)_{\max } \mathrm{A}$,

where $X^{*}$ and $\left(X_{b}\right)_{\max }$ are the steady state values of suspended cell density and the biofilm cell number per unit surface area, respectively. The cell growth rate in bulk in steady state may be obtained once $\mu_{\text {biofilm }}^{*}$ is known.

$\mu_{\text {bulk }}^{*}=\frac{Q\left(X^{*}-X_{\text {in }}\right)-\mu_{\text {biofilm }}^{*}\left(X_{\mathrm{b}}\right)_{\max } \mathrm{A}}{X^{*} \mathrm{~V}}$.

Defining an overall specific cell growth rate, $\mu_{\text {overall, as a }}$ weighed average of the cell growth rates in the biofilm and in the bulk water (Boe-Hansen et al., 2002b), then

$\mu_{\text {overall }}\left(\mathrm{XV}+\mathrm{X}_{\mathrm{b}} \mathrm{A}\right)=\mu_{\mathrm{bulk}} \mathrm{XV}+\mu_{\text {biofilm }} \mathrm{X}_{\mathrm{b}} \mathrm{A}$.

Therefore, taking into account Eq. (11), the steady state overall specific rate growth can also be given by

$\mu_{\text {overall }}^{*}=\frac{Q\left(X^{*}-X_{\text {in }}\right)}{X^{*} V+\left(X_{b}\right)_{\max } A}$.

\subsection{Statistics}

The experimental data were analyzed using the computer program SPSS (version 13.00, UTHSCSA). The statistics were performed with the Levene's homogeneity of variance test, the one-way analysis of variance, the Tukey honestly significant difference and the Tamhane's T2 post hoc tests. Mean comparisons were performed with significant level of $p<0.05$. Ninety-five percent confidence intervals were calculated assuming a normal distribution based on the standard deviation and the number of samples.

\section{Results and discussion}

\subsection{Suspended cells in bulk water}

In the experimental RUN 1, water samples from the three reactors and from the tap were regularly collected and analyzed at time zero and at different times between operation days 5 and 56. The physico-chemical parameters (Table 4) presented almost constant values over time. The slightly lower temperatures registered in the Propella ${ }^{\circledR}$ are due to the fact that this reactor was installed in a colder room. In RUN 2, several samples were collected from the first day until day 28 , and the measured physico-chemical parameters 

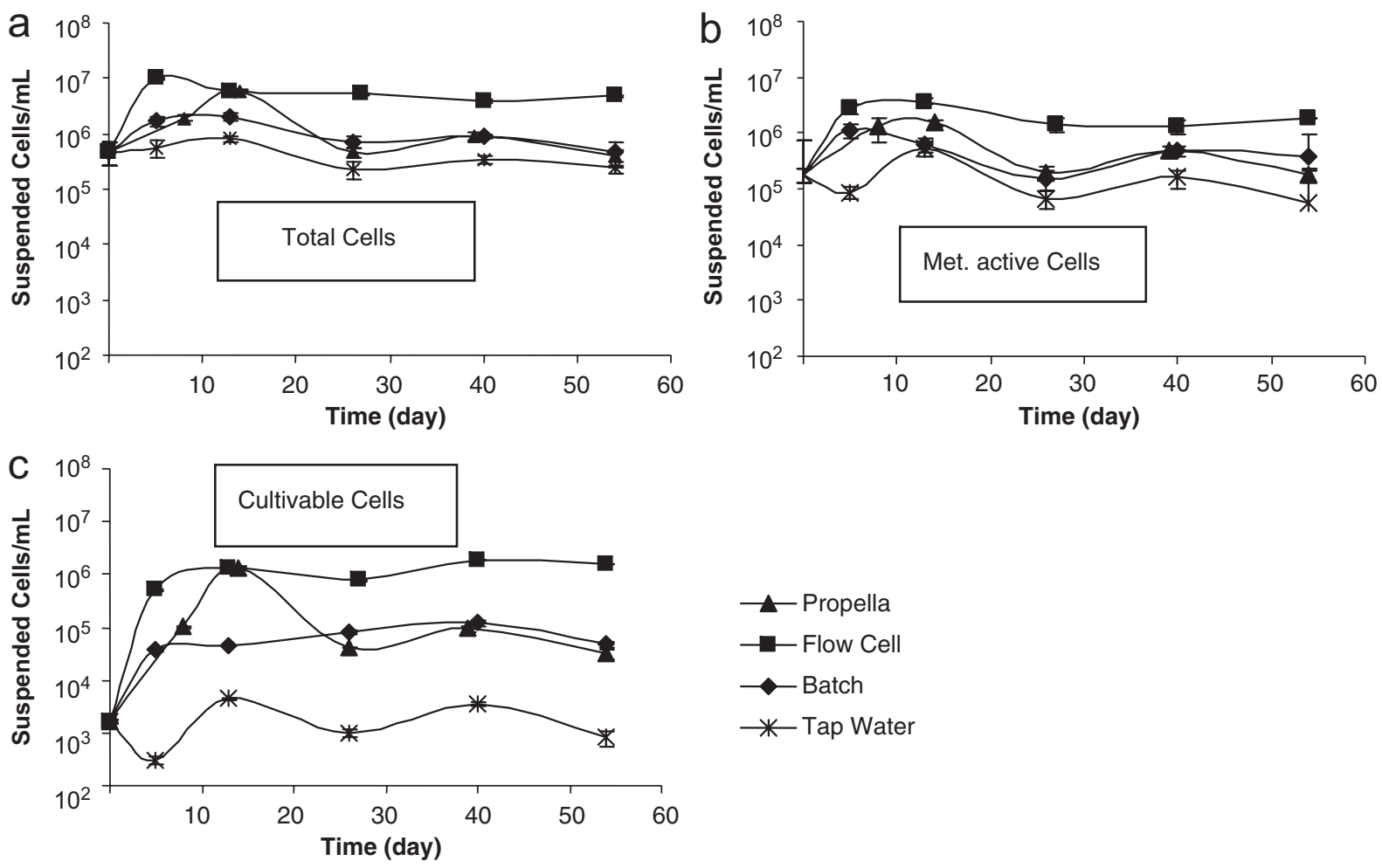

Fig. 3 - Cell densities in bulk water: (a) total cells; (b) metabolically active cells and (c) $R_{2} A$-cultivable cells for the indicated biofilm monitoring reactors in RUN 1 and in tap water.

of the bulk water were generally similar to those of RUN 1 (Table 4).

The densities of cells in the bulk water of the three reactors and in the feeding tap water for RUN 1 are plotted in Fig. 3. In all reactors, a quasi-steady state was achieved after 5 operation days, since suspended cell densities were thereon constant with time, although with some fluctuations. The cell densities decreased in the order of total, metabolically active and $\mathrm{R}_{2} \mathrm{~A}$-cultivable cells for each water system tested. Around $35-50 \%$ of the total cells were metabolically active and fewer (5-20\%) were able to form colony units in $\mathrm{R}_{2} \mathrm{~A}$ medium.

In the Flow Cell assay with a higher internal velocity (RUN 2), data show that the steady state was reached after 2-3 days of operation with $1.8 \times 10^{7} \pm 3.1 \times 10^{6}$ total suspended cells/ $\mathrm{mL}$. This value is around three times higher than that observed in RUN 1 inside the Flow Cell reactor, which was $6.1 \times 10^{6} \pm 3.1 \times 10^{5}$ total suspended cells $/ \mathrm{mL}$. The increase in the bulk water densities with internal velocity may indicate a higher detachment rate and a possible higher planktonic growth due to an increase of the average temperature.

In RUN 1, the total cell numbers per milliliter in the bulk water were 10-fold higher in the Flow Cell than in the Propella ${ }^{\circledR}$ reactor.

Total suspended cell density in the Batch reactor was lower than in the Flow Cell, since there is no additional feed of biomass or nutrients after loading the reactor. As expected, inlet tap water presented the lowest values of suspended cells, since residence times and temperatures are higher inside the reactors.

\subsection{Cells in biofilms}

Biofilm samples were collected during the quasi-steady state phase for microbiological analysis and the results are presented in Fig. 4 for assays with the Propella ${ }^{\circledR}$, Flow Cell and Batch reactors containing the PVC coupons (RUN 1). The values of total, metabolically active and $R_{2} A$ cultivable cells obtained in the continuous reactors were higher than in the Batch reactor. This could be due to the fact that in the continuous systems the dilution rate was much higher than the microbial growth rates, which is known to stimulate adhesion (Heijnen et al., 1992). The cell numbers observed for biofilms grown in the Propella ${ }^{\circledR}$ and Flow Cell were similar and higher than in the Batch system.

As in the case of suspended cells, the biofilm total cells per square centimeter were always higher than the metabolically active cells and these were higher than the cultivable cells grown on PVC at each sampling time. Similar results were found by Schaule et al. (1993), Kalmbach et al. (1997), Schwartz et al. (1998), Boe-Hansen et al. (2002b) and Wingender and Flemming (2004). Around $17-35 \%$ of the total cells were metabolically active and $8-15 \%$ were cultivable in $\mathrm{R}_{2} \mathrm{~A}$ medium. These percentages of metabolically active cells are within the ranges reported by Kalmbach et al. (1997), Schaule et al. (1993) and Schwartz et al. (1998). The data on cultivable cells agree with those published by Schwartz et al. (1998), who studied biofilms of 9-36 days, similar to those reported in the present paper (5-56 days). All the other authors based their work on much older biofilms 

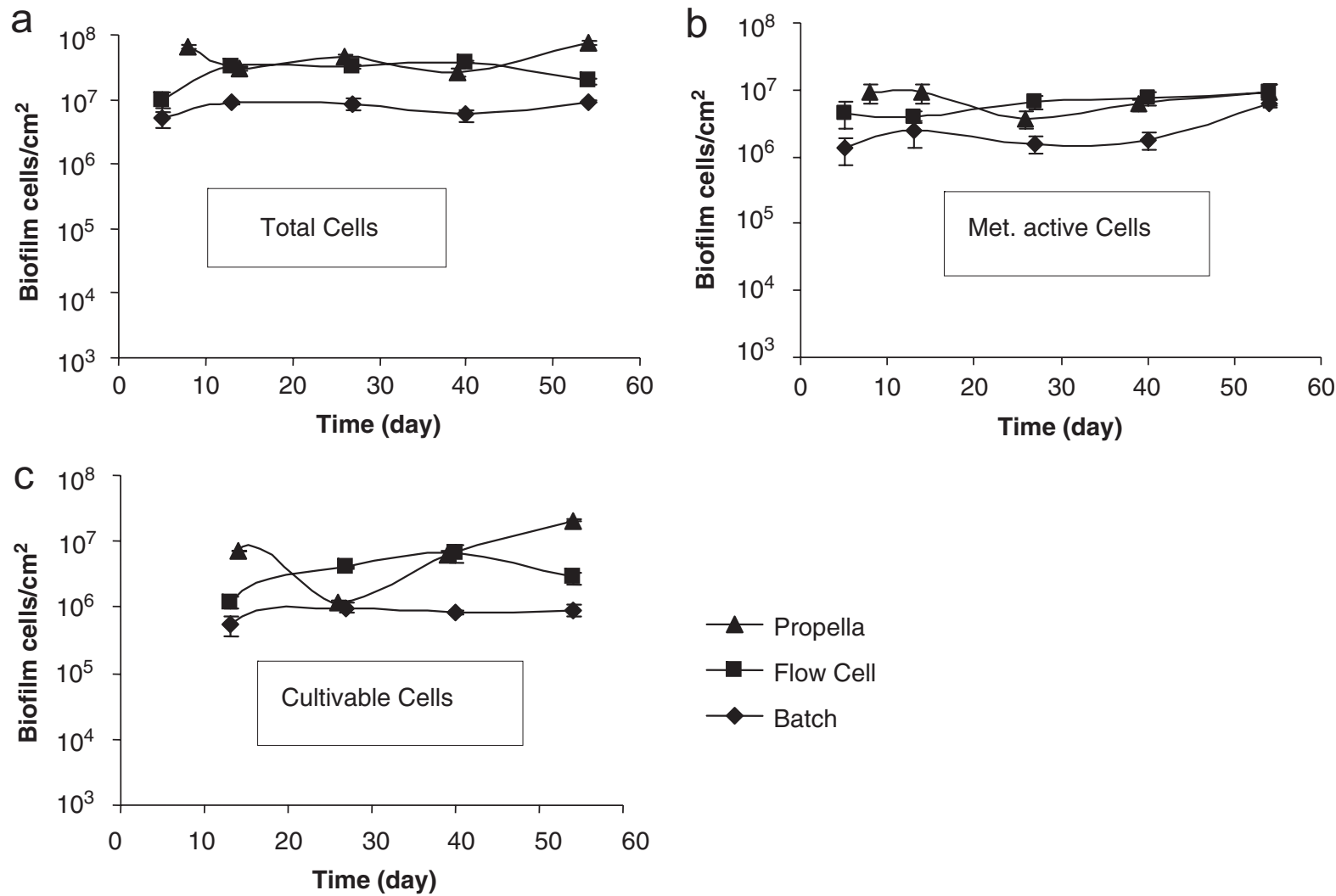

Fig. 4 - Attached cells per unit surface area of the biofilm grown on PVC in RUN 1: (a) total cells; (b) metabolically active cells and (c) $R_{2} A$-cultivable cells.
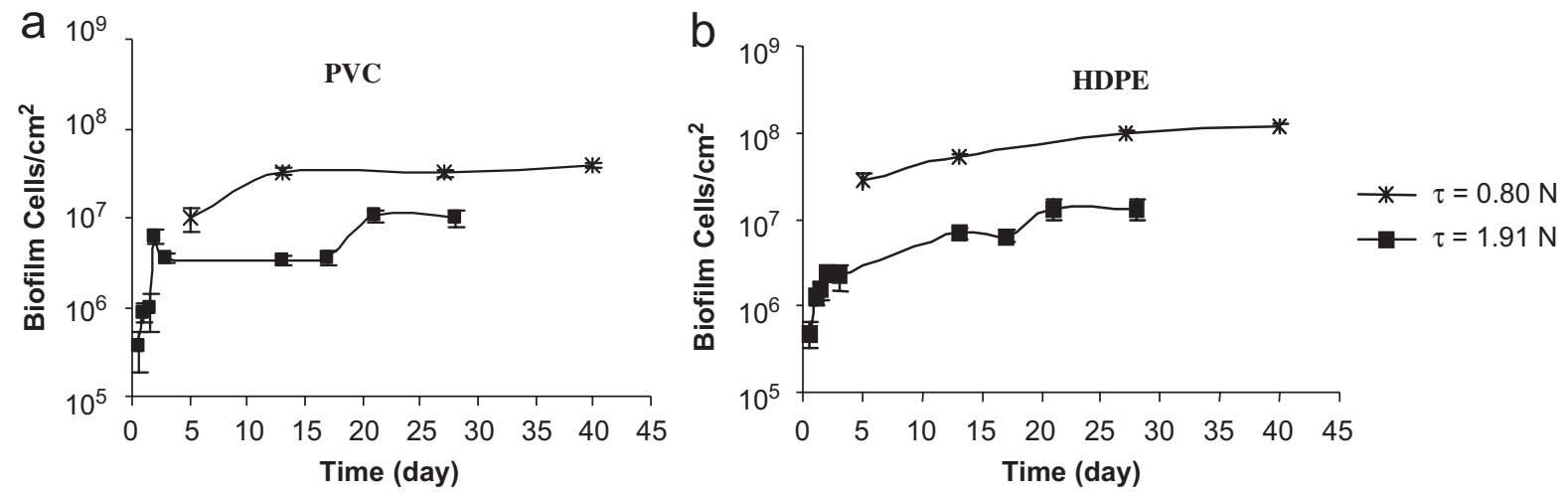

Fig. 5 - Total attached cells per unit surface area of biofilm grown on: (a) PVC and (b) HDPE; in the Flow Cell with two different shear stresses (RUN 1-lower shear stress and RUN 2-higher shear stress).

(6 months-99 years), which may explain the loss of cultivability of cells (less than $4 \%$ of cultivable cells).

Fig. 5 compares the total cell numbers per unit surface area for biofilms grown on PVC and HDPE under different flow velocities (RUN 1 and RUN 2). Increasing the shear stress resulted in lower cell numbers per unit surface area on both materials: for PVC, in steady state, $2.6 \times 10^{7}$ cells $/ \mathrm{cm}^{2}$ $\left( \pm 5.7 \times 10^{6}\right)$ and $6.1 \times 10^{6} \mathrm{cells} / \mathrm{cm}^{2}\left( \pm 2.5 \times 10^{6}\right)$ for $\tau_{\mathrm{w}}=0.8$ and $1.91 \mathrm{~Pa}$, respectively; for HDPE, the values were $8.7 \times 10^{7} \mathrm{cells} / \mathrm{cm}^{2} \quad\left( \pm 1.2 \times 10^{7}\right) \quad$ and $8.2 \times 10^{6} \mathrm{cells} / \mathrm{cm}^{2}$ $\left( \pm 1.3 \times 10^{6}\right)$ for $\tau_{\mathrm{w}}=0.8$ and $1.91 \mathrm{~Pa}$, respectively. This effect is usually observed in biofilms formed under turbulent flow conditions (Pinheiro et al., 1988; Bott, 1995).

\subsection{Suspended cells versus biofilm cells}

In Fig. 6, the total attached cells per unit surface area are plotted against the total suspended cell density for biofilms grown on PVC and HDPE at quasi-steady state in RUN 1. Apparently, no meaningful dependency can be detected 


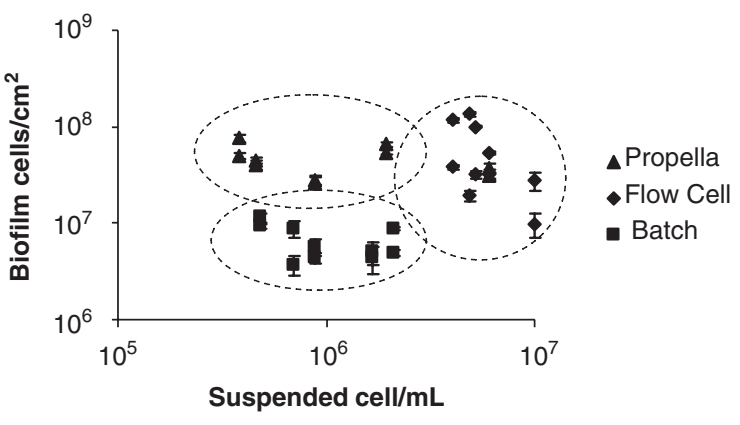

Fig. 6 - Total attached cells per unit surface area of biofilm versus total suspended cell density in RUN 1 for Propella ${ }^{\circledR}$, Flow Cell and batch reactors.

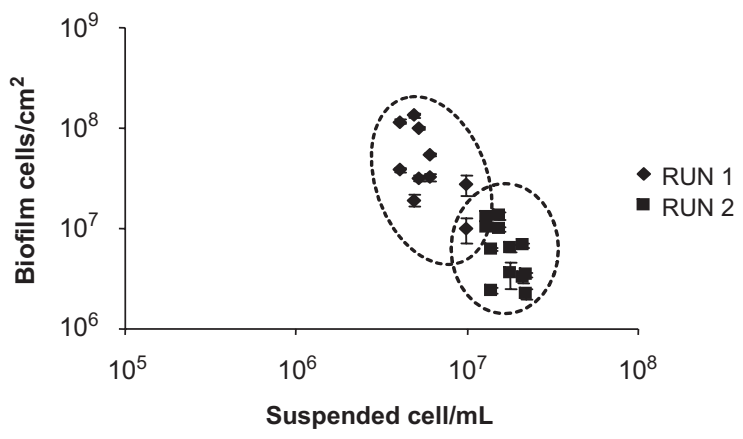

Fig. 7 - Total attached cells per unit surface area of biofilm versus total suspended cell density in Flow Cell for: (a) RUN $1(0.21 \mathrm{~m} / \mathrm{s})$ and (b) RUN2 $(0.34 \mathrm{~m} / \mathrm{s})$.

between suspended and biofilm total cells. Similar conclusions can be drawn from the analysis of the steady state results of RUN 2 (Fig. 7).

It is interesting to note that the average ratio between attached and suspended cells in the quasi-steady state period depended on the reactor type, being much higher in the Propella system (about 50) than in the Flow Cell (about 10), cf. Fig. 6. Two factors may explain this behaviour: firstly, the average temperature is higher in the Flow Cell; secondly, although equal water velocities were used in the Propella ${ }^{\circledR}$ and Flow Cell reactors, the Reynolds number was 25\% higher in the Flow Cell system, which should indicate a higher degree of turbulence intensity in this reactor (this is due to differences in the hydraulic diameter and cross section shape of the two reactors which imply different hydrodynamic patterns). A lower attached cells/suspended cells ratio was found when a higher velocity was used in the same reactor (Flow Cell, RUNS 1 and 2), independently of the surface material. This may be due to an increase in the flow velocity (hence, shear stress) and Reynolds number (and, therefore, degree of turbulence) from RUN 1 to RUN 2 in the Flow Cell.

The data in Fig. 6 also suggest that in steady-state the attached cells number is not controlled by the suspended cells number, as observed before by Bott and Miller (1983) and Melo and Vieira (1999). Although suspended cells may still attach to the surface and participate to the biofilm formation, their contribution seems to have a minor effect when compared to the internal growth of the attached cells. Nutrients, chemical parameters ( $\mathrm{pH}$, biocides, etc.) and hydrodynamics seem to be the most important factors that condition biofilm growth rates (Pedersen, 1990; Bott, 1995; Kerr et al., 1999; Batté et al., 2003), except when there is significant release of nutrients from the surface material to the water (Lethola et al., 2004, 2005).

\subsection{Effect of surface material on biofilm formation}

Drinking water biofilms were grown on common polymeric surfaces (PVC, PEX, HDPE and PP) using the Propella ${ }^{\circledR}$, Flow Cell and Batch reactors, and the data obtained in quasi-steady state are presented in Fig. 8. The results followed the trends already observed showing that for all reactors $17-35 \%$ of the total cells were CTC-reducing cells and $6-18 \%$ were cells able to form colony units.

Comparing the results in the three reactors, the average total cell numbers per unit surface area in quasi-steady state were similar in the two continuous flow systems and higher than in the Batch reactor, independently of the material $(p<0.05)$. For each reactor, it can be said that the quasi-steady state biofilm amount was not greatly affected by the tested surface material; the same occurred with the biofilm relative composition in terms of metabolically active versus total cells, indicating that the active fraction of biofilms did not depend on the surface composition. Therefore, it seems that the growth potential of the biofilms was also not affected by the adhesion surface. It should be emphasized, however, that the biofilms in this study were rather young and that almost stable conditions were kept during the assays, as opposed to what happens in a real drinking water distribution network. The results here presented are in accordance with work from several authors, but they are at variance with others (as summarized in the Introduction section of this paper). Clearly, the surface factor still requires a systematic experimental analysis, where the various variables (surface composition and roughness, biofilm age, nutrient release from the surface, hydrodynamic conditions, environmental stability) are taken into account and duly controlled.

\subsection{Specific growth rates in biofilms and in bulk water}

In order to assess the kinetics of biofilm development and compare it to the suspended cell growth rates, tests were carried out in the Flow Cell (RUN 2) where a higher number of biofilm and water samples were collected during the initial phase (transient period) of biofilm formation. The results are presented in Fig. 9 for biofilms grown on PVC and HDPE.

The data from RUN 2 was used to calculate specific growth rates in the biofilm, as presented in Table 5 . The maximum total cell number per unit surface area, $\left(X_{b}\right)_{\max }$ was obtained from data at steady state (Fig. 9) and the biofilm production rate, $\Phi_{\mathrm{p}}$, was determined from the data obtained in the initial period of biofilm formation by fitting Eq. (6), which allowed $\mu_{\text {biofilm }}^{*}$ to be calculated with Eq. (9). Finally, $\mu_{\text {bulk }}^{*}$ was calculated with Eq. (11) and the overall specific growth rate,

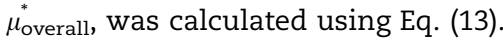



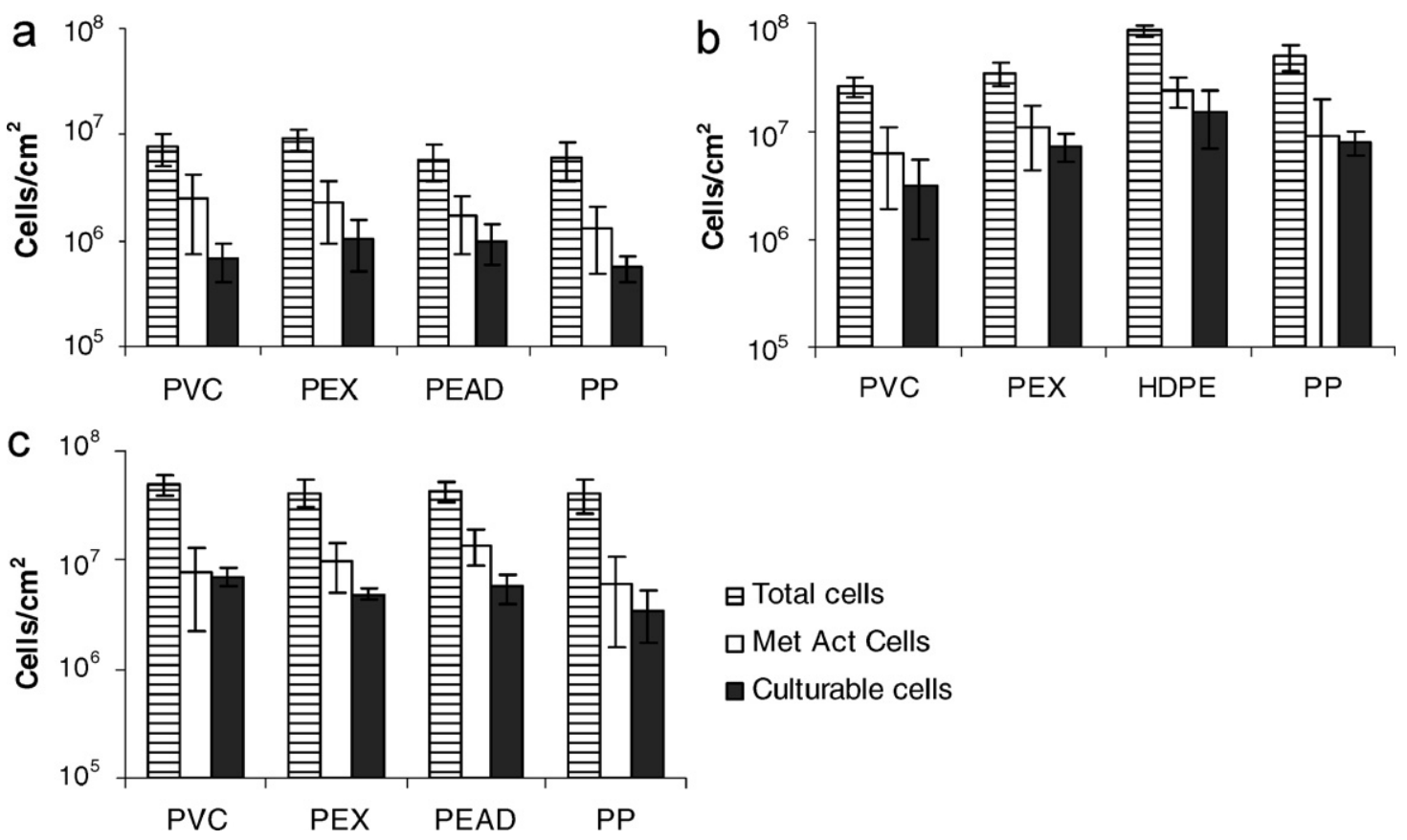

Fig. 8 - Attached cells per unit surface area at quasi-steady state in RUN 1 (total and metabolically active cells) for biofilms grown on different polymeric surfaces (PVC, PEX, HDPE and PP) in: (a) batch reactor, (b) Flow Cell and (c) Propella ${ }^{\circledR}$.
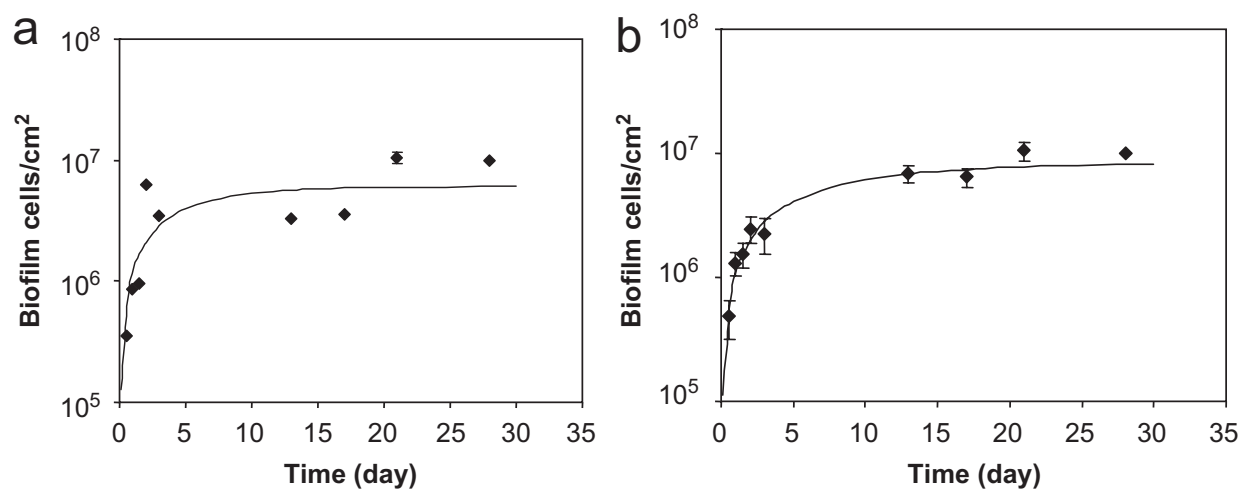

Fig. 9 - Biofilm cells per unit surface area of biofilms grown on: (a) PVC and (b) HDPE, in RUN 2. Eq. (6) is represented by the continuous line.

\section{Table 5 - Specific cell growth rates at steady state (RUN 2)}

\begin{tabular}{lcc}
\hline & PVC & HDPE \\
\hline$(\mathrm{Xb})_{\max }\left(\mathrm{cell} / \mathrm{cm}^{2}\right)$ & $6.1 \times 10^{6} \pm 2.5 \times 10^{6}$ & $8.2 \times 10^{6} \pm 1.3 \times 10^{6}$ \\
$\Phi_{\mathrm{p}}\left(\mathrm{cell} /\right.$ day $^{6}$ & $2.5 \times 10^{2} \pm 1.4 \times 10^{2}$ & $3.1 \times 10^{2} \pm 8.6 \times 10^{1}$ \\
$\mu_{\text {biofilm }}\left(\right.$ day $\left.^{-1}\right)$ & $0.15 \pm 0.09$ & $0.14 \pm 0.05$ \\
$\mu_{\text {bulk }}^{*}\left(\right.$ day $\left.^{-1}\right)$ & $1.8 \pm 0.1$ & $1.8 \pm 0.1$ \\
$\mu_{\text {overall }}^{*}\left(\right.$ day $\left.^{-1}\right)$ & $1.4 \pm 0.2$ & $1.3 \pm 0.2$ \\
\hline
\end{tabular}

The values of the specific growth rates obtained for biofilms grown on PVC and HDPE (Table 5) are not statistically different $(p>0.05)$, meaning that the surface material had no visible effect on the biofilm growth. It should also be emphasized that the average specific growth rates of cells in the biofilm were much lower than those in the microbial suspension (bulk water), which agrees with the published literature in the last decade (Lappin-Scott and Costerton, 1995) where the metabolic state of attached cells was reported to be different from the one in suspended cultures. It should be noted that the specific growth rate in the liquid suspension is similar to the inverse of the hydraulic residence time, which is in accordance with the chemostat principles.

Pedersen (1990), Block et al. (1993) and Boe-Hansen et al. $(2002 a, b)$ reported lower growth rates for cells in drinking water biofilms, probably due to different shear stresses, lower temperatures of the water or chlorinated systems. The results of Boe-Hansen et al. (2002b) for specific growth rates in bulk water are around 10 times higher than in biofilm, as in the present work. Other authors 
determined biofilm kinetics in wastewater and industrial cooling water systems and concluded that cell growth kinetics in biofilms was slower than in suspension (Wiesmann, 1994; Vieira and Melo, 1999). For example, specific growth rates of Pseudomonas fluorescens in suspended cultures are of the order of $10^{-1} \mathrm{~h}^{-1}$ (Robinson et al., 1984), but the values found for the same cells in a biofilm (Vieira and Melo, 1999) were 10 times lower. However, as opposed to the present case, those biofilms were quite thick $(200-700 \mu \mathrm{m})$ and contained significant amounts of EPS that contributed to internal diffusional limitations and, possibly, to different metabolic states of the bacteria located along the depth of the biofilm matrix. In the present work, the biofilms were very thin and essentially composed by cell colonies; no EPS could be detected with the available methods. This fact may be related to the scarcity of nutrients in properly treated drinking water, as compared to wastewater or industrial cooling waters, and to the presence of disinfectants.

Using the values obtained for $\left(\mathrm{X}_{\mathrm{b}}\right)_{\max }$ and $\mu_{\mathrm{biofilm}}^{*}$, the asymptotic model (Eq. (6)) is represented in Fig. 9 (continuous line) and gives a satisfactory fit of the experimental trends. This model assumes that steady state is achieved when there is a balance between biofilm removal and growth, which is just a conceptual approach because these events do not happen continuously and with the same extent. That is why some uncertainty exists that is not described by the model, as observed in Fig. 9.

\section{Conclusions}

(1) The study of biofilm formation in drinking water systems under the same flow velocity (Propella ${ }^{\circledR}$ and Flow Cell reactors) and stagnant conditions (non-stirred Batch reactor) showed that the total cell counts per unit surface area were around one order of magnitude higher in the flow reactors than in the Batch reactor. Although the Flow Cell and Propella ${ }^{\circledR}$ reactors have completely different designs, their performance was similar as regards bacterial accumulation on surfaces under the same flow velocity. However, the ratio of attached cells to suspended cells in the Propella ${ }^{\mathbb{R}}$ was much higher than in the Flow Cell for the same velocity. This can be the result of higher temperature and Reynolds number in the Flow Cell, as well as of differences in the ratio volume/area and reactor design.

(2) The various surface materials tested (PVC, HDPE, PEX and PP) did not affect bacterial accumulation both in flow situations and in stagnant waters. In quasi-steady state, the metabolically active bacteria in biofilms were around $17-34 \%$ of the total cells and $6-18 \%$ were able to form colony units in $R_{2} A$, regardless the surface materials and reactor geometry. Similarly, the percentages of suspended metabolically active and cultivable cells in the bulk waters inside the reactors were $35-50 \%$ and $5-20 \%$ of the total cells, respectively.

(3) In steady state, the specific cell growth rate in the biofilm,

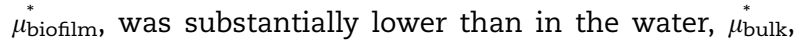
(0.14-0.15 day $^{-1}$ versus 1.8 day $^{-1}$ ). The overall specific cell growth rate, $\mu_{\text {overall }}^{*}$ (a weighed average value, which indicates the growth potential in the whole system, including suspended and attached biomass), was similar with both surface materials (around 1.3-1.4 day ${ }^{-1}$ ).

\section{Acknowledgements}

The work has been undertaken as part of the research project SAFER ("Surveillance and control of microbiological stability in drinking water distribution networks"), which is supported by the European Commission within the Fifth Framework Programme, "Energy, Environment and sustainable development programme" (contract no. EVK1-CT-2002-00108).

R E F E R E N C E S

Batté, M., Appenzeller, B.M.R., Grandjean, D., Fass, S., Gauthier, V., Jorand, F., Mathieu, L., Boualam, M., Saby, S., Block, J.-C., 2003. Biofilms in drinking water distribution systems. Rev. Environ. Sci. Biotechnol. 2, 147-168.

Bakke, R., Trulear, M.G., Robinson, J.A., Characklis, W.G., 1984. Activity of Pseudomonas aeruginosa in Biofilms: steady state. Biotechnol. Bioeng. XXVI, 1418-1424.

Belkhadir, FR., Capdeville, B., Roques, H., 1988. Fundamental descriptive study and modelization of biological film growth. Water Res. 22 (1), 59-69.

Block, J.C., Haudidier, K., Paquin, J.L., Miaza, J., Levi, Y., 1993. Biofilm accumulation in drinking water distribution systems. Biofouling 6, 333-343.

Boe-Hansen, R., Albrechtsen, H.J., Arvin, E., Jorgensen, C., 2002a. Dynamics of biofilm formation in a model drinking water distribution system. J. Water Supply Res. Technol.-Aqua 51, 399-406.

Boe-Hansen, R., Albrechtsen, H.-J., Arvin, E., Jorgensen, C., 2002b. Bulk water phase and biofilm growth in drinking water at low nutrient conditions. Water Res. 36 (18), 4477-4486.

Bott, T.R., 1995. Fouling of Heat Exchangers. Elsevier Science, Amsterdam (Chapter 12).

Bott, T.R., Miller, P.C., 1983. Mechanisms of biofilm formation on aluminium tubes. J. Chem. Tech. Biotech. 33 (B), 177-184.

Brunk, C., Jones, K., James, T., 1979. Assay for nanogram quantities of DNA in cellular homogenates. Anal. Biochem. 92, 497-500.

Characklis, W.G., Marshall, K., 1990. Biofilms. John Wiley \& Sons, New York.

Clark, R.M., Lykinf, B.W., Block, J.C., Wymer, L.J., Reasoner, D.J., 1994. Water quality changes in a simulated distribution system. J. Water Supply Res. Technol. Aqua 43 (6), 263-277.

Cloete, T.E., Westaard, D., van Vuuren, S.J., 2003. Dynamic response of biofilm to pipe surface and fluid velocity. Water Sci. Technol. 47 (5), 57-59.

Flemming, H.C., Percival, S.L., Walker, J.T., 2002. Contamination potential of biofilms in water distribution systems. Water Sci. Technol. Water Supply 2 (1), 271-280.

Heijnen, J.J., van Loosdrecht, M.C.M., Mulder, A., Tijhuis, L., 1992. Formation of biofilms in a biofilm air-lift suspension reactor. Water Sci. Technol. 26, 647-654.

Kalmbach, S., Manz, W., Szewzyk, U., 1997. Dynamics of biofilm formation in drinking water: Phylogenetic affiliation and metabolic potential of single cells assessed by formazan reduction and in situ hybridization. FEMS Microbiol. Ecol. 22 (4), 265-279.

Kerr, C.J., Osborn, K.S., Roboson, G.D., Handley, P.S., 1999. The relationship between pipe material and biofilm formation in a laboratory model system. J. Appl. Microbiol. 85, 29s-38s. 
Lappin-Scott, H.M., Costerton, J.W. (Eds.), 1995. Microbial Films, Cambridge University Press, Cambridge.

Le Magrex, E., Brisset, L., Jacquelin, L.F., Carquin, J., Bonnaveiro, N., Choisy, C., 1994. Susceptibility to antibacterials and compared metabolism of suspended bacteria versus embedded bacteria in biofilms. Colloids Surfaces B Biointerfaces 2, 89-95.

LeChevallier, M.W., Babcock, T.M., Lee, R.G., 1987. Examination and characterization of distribution system biofilms. Appl. Environ. Microbiol. 53 (12), 2714-2724.

Lehtola, M.J., Miettinen, I.T., Keinãnen, M.M., Kekki, T., Laine, O., Hirvonen, A., Vartiainen, T., Martikainen, P., 2004. Microbiology, chemistry and biofilm development in a pilot drinking water distribution system with copper and plastic pipes. Water Res. 38 (17), 3769-3779.

Lehtola, M.J., Miettinen, I.T., Lampola, T., Hirvonen, A., Vartiainen, T., Martikainen, P.J., 2005. Pipeline materials modify the effectiveness of disinfectants in drinking water distribution systems. Water Res. 39 (10), 1962-1971.

Melo, L.F., Bott, T.R., 1997. Biofouling in water systems. Exp. Therm. Fluid Sci. 14 (4), 375-381.

Melo, L.F., Vieira, M.J., 1999. Physical stability and biological activity of biofilms under turbulent flow and low substrate concentration. Bioprocess Eng. 20 (4), 363-368.

Momba, M.N.B., Kaleni, P., 2002. Regrowth and survival of indicator microorganisms on the surfaces of household containers used for the storage of drinking water in rural communities of South Africa. Water Res. 36 (12), 3023-3028.

Niquette, P., Servais, P., Savoir, R., 2000. Impacts of pipe materials on densities of fixed bacterial biomass in a drinking water distribution system. Water Res. 34 (6), 1952-1956.

Pedersen, K., 1990. Biofilm development on stainless steel and PVC surfaces in drinking water. Water Res. 24 (2), 239-243.

Pereira, M.O., Kuehn, M., Wuertz, S., Neu, T.R., Melo, L.F., 2002. Effect of Flow Regime on the Architecture of a Pseudomonas fluorescens Biofilm. Biotechnol. Bioeng. 78, 164-171.

Peyton, B.M., Characklis, W.G., 1993. A statistical analysis of the effect of substrate utilization and shear stress on the kinetics of biofilm detachment. Biotechnol. Bioeng. 41 (7), 728-735.

Pinheiro, M.M., Melo, L.F., Bott, T.R., Pinheiro, J.D., Leitão, M.L., 1988. Surface phenomena and hydrodynamic effects on the deposition of Pseudomonas fluorescens. Can. J. Chem. Eng. 66, 66-70.

Plas, C., Holubar, P., Braun, R., 1994. Activity of immobilized and suspended thiobacilli-monitoring immobilization kinetics. Colloids Surfaces B Biointerfaces 2, 97-101.

Reasoner, D.J., Geldreich, E.E., 1985. A new medium for the enumeration and subculture of bacteria from potable water. Appl. Environ. Microbiol. 49 (1), 1-7.

Robinson, J.A., Trulear, M.G., Characklis, W.G., 1984. Cellular reproduction and extracellular polymer formation by Pseudomonas aeruginosa in continuous culture. Biotechnol. Bioeng. XXVI, 1409-1417.

Rodriguez, G.G., Phipps, D., Ishiguro, K., Ridgway, H.F., 1992. Use a fluorescent redox probe for direct visualization of actively respiring bacteria. Appl. Environ. Microbiol. 58 (6), 1801-1808.

Schaule, G., Flemming, H.C., Ridgway, H.F., 1993. Use of 5-cyano2,3-ditolyl tetrazolium chloride for quantifying planktonic and sessile respiring bacteria in drinking water. Appl. Environ. Microbiol. 59 (11), 3850-3857.

Schwartz, T., Hoffmann, S., Obst, U., 1998. Formation and bacterial composition of young, natural biofilms obtained from public bank-filtered drinking water systems. Water Res. 32 (9), 2787-2797.

van der Kooij, D., Veenendaal, H.R., 2001. Biomass production potential of materials in contact with drinking water: method and practical importance. Water Sci. Technol. Water Supply 1 (3), 39-45.

van der Wende, E., Characklis, W.G., Smith, D.B., 1989. Biofilms and bacterial drinking water quality. Water Res. 23 (10), 1313-1322.

Vieira, M.J., Melo, L.F., 1999. Intrinsic kinetics of biofilms formed under turbulent flow and low substrate concentrations. Bioprocess. Eng. 20, 369-375.

Wiesmann, U., 1994. Biological nitrogen removal from wastewater. Adv. Biochem. Eng. Biotechnol. 51, 113-154.

Wingender, J., Flemming, H.C., 2004. Contamination potential of drinking water distribution network biofilms. Water Sci. Technol. 49 (11-12), 277-286.

Zacheus, O.M., Iivanainen, E.K., Nissinen, T.K., Lehtola, M.J., Martikainen, P.J., 2000. Bacterial biofilm formation on polyvinyl chloride, polyethylene and stainless steel exposed to ozonated water. Water Res. 34 (1), 63-70. 